\title{
PEMETAAN KEBISINGAN PADA KAWASAN PENDIDIKAN AKIBAT TRANSPORTASI DI AREA ZOSS (ZONA SELAMAT SEKOLAH) DI KOTA PONTIANAK
}

Ade Supriyatno $^{1)}$ Kiki Prio Utomo ${ }^{1)}$ Dian Rahayu Jati ${ }^{11}$

1) Program Studi Teknik Lingkungan Jurusan Teknik Sipil Fakultas Teknik Universitas Tanjungpura, Pontianak Email : Adesupriyatno4@gmail.com

\begin{abstract}
ABSTRAK
Penelitian ini dilaksanakan pada kawasan sekolah kota Pontianak yaitu SDN 17, TK Pertiwi dan SMPN 9 kota Pontianak yang memiliki ZoSS (Zona Selamat Sekolah) yang dibangun pada tahun 2015. Berdasarkan Pada pasal 31 Perda No 2 Tahun 2013 tentang RTRW 2013-2033 di sebutkan bahwa kawasan peruntukan pelayanan umum yaitu kawasan pendidikan seharusnya berada di jalan Ampera di kelurahan Sungai Jawi kecamatan Pontianak kota. Hal ini tentunya tidak sesuai dengan yang terjadi di lokasi sesungguhnya, dimana lokasi sekolah yang masih berada di kawasan yang bukan di peruntukan khusus untuk sekolah. SDN 17 berlokasi di Jalan Putri Candramidi kota pontianak, TK Pertiwi berlokasi di jalan K.H A. Dahlan, dan SMPN 9 berlokasi di jalan Pengeran Natakusuma dimana ketiga jalan termasuk daerah yang cukup padat transportasinya di kota Pontianak. Penelitian ini bertujuan untuk menganalisis tingkat kebisingan, memetakan sebaran tingkat kebisingan, dan membuat upaya penanggulangan akibat tingkat kebisingan di masing-masing lokasi. Penentuan titik pengukuran dilakukan pada aplikasi google earth, yang kemudian pada saat di lapangan titik koordinatnya diambil menggunakan aplikasi GPS. Pengukuran tingkat kebisingan pada penelitian dengan menggunakan alat Sound Level Meter. Pengukuran dilakukan selama 10 menit pada setiap titik, dan data yang diperoleh adalah data tingkat kebisingan dengan mengacu pada SNI 7231:2009. Pemetaan sebaran tingkat kebisingan menggunakan aplikasi surfer 11. Berdasarkan hasil penelitian didapatkan bahwa tingkat kebisingan di SDN 17, TK Pertiwi dan SMPN 9 kota Pontianak melebihi baku mutu ambang batas kebisingan untuk kawasan pendidikan dalam hal ini sekolah yang tertuang dalam Keputusan Menteri Negara Lingkungan Hidup Nomor KEP.48/MENLH/11/1996 yaitu sebesar 55 dB. Berdasarkan hasil penelitian bahwa nilai tingkat kebisingan tertinggi adalah 72,8 dBdenganjarakbangunansekolahterhadapjalanraya $13 \mathrm{~m}$, yaitu pada SDN 17 kota Pontianak. Tingkat kebisingan terendah terdapat pada SMPN 9 kota Pontianak yaitu dengan nilai kebisingan 52,3 dBdenganjarakbangunansekolahterhadapjalanraya $40 \mathrm{~m}$. Peta sebaran tingkat kebisingan di kawasan pendidikan kota pontianak dominan berwarna kuning dan merah, yang artinya tingkat kebisingan di area sekolah rata-rata di antara 60-70 dB. Upaya untuk meminimalisir kebisingan dari aktivitas transportasi di Pontianak yaitu membuat BPB dapat berupa penghalang alami (natural barrier) dan penghalang buatan (artificial barrier), Menmbahkan tanaman yang dapat meredam bising. Serta untuk pemerintah kota bisa membuat kebijakan mengenai pemakaian moda transportasi umum.
\end{abstract}

Kata Kunci :Zoss, sekolah, surfer 11, pemetaan kebisingan

\begin{abstract}
This research was carried out on the area of the city of Pontianak school namely, TK 17 Pertiwi SDN and 2289 Pontianak town which has ZoSS (school safety zone) which was built in the year 2015. Based on article 31 Perda No. 22013 on RTRW 2013-2033 mentioned that in the area of public services namely allotment area of education should be on the road the Ampera in kelurahan Sungai Jawi subdistrict of Pontianak town. This is certainly not as happening in real locations, where the location of the school which still is not in the special allocation to the school. SDN 17 is located on street Putri Candramidi pontianak town, TK Pertiwi is located on street K. H. A. Dahlan, and SMPN 9 is located on street Pangeran Natakusuma the third way in which includes a pretty solid areas of transportation in the city of Pontianak.. This research aims to analyze the noise level, mapped the distribution of noise levels, and make efforts to combat due to the noise level in each location. Determination of the measurement point is done on the google earth application, which later on when its own coordinate point taken in the field using GPS applications. The measurement of the noise level on research using a Sound Level Meter. The measurements were made during 10 minutes at any point, and the data obtained is the noise level data with reference to the SNI 7231:2009. Mapping the distribution of noise levels using surfer applications 11. Based on the research results obtained that the noise level in the SDN 17, TK Pertiwi and SMPN 9 Pontianak town exceeded the threshold of quality raw noise to the area of education in this school that are contained in the decision of the Minister of State for the environment Number KEP. 48/MENLH/11/1996, namely of $55 \mathrm{~dB}$. Based on the results of research that the value of the highest noise level $d B$ at a distance of 72.8 is school buildings against Highway 13 m, namely on SDN 17 Pontianak town. Lowest noise level present in SMPN 9 city of Pontianak namely with 52.3 noise $d B$ value to the distance the school
\end{abstract}


building towards Highway $40 \mathrm{~m}$. Map the spread of noise levels in the area of education of the city of pontianak dominant yellow and red, meaning that the noise level at the area schools average between 60-70 $d B$. Efforts to minimize noise from transportation activities in Pontianak, namely making BPB can be either a natural barrier (natural barrier) and artificial barriers (artificial barrier), Menmbahkan plant that can dampen noise. As well as for the City Government could make policy regarding the use of public transportation.

Keywords : Zoss, school, Surfer11, noise mapping

\section{Pendahuluan}

Kota Pontianak saat ini merupakan kota yang sedang berkembang dengan pembangunan yang sangat pesat, hal ini dapat dilihat dari perkembangan pembangunan dan ekonomi yang cukup pesat. Akibat dari perkembangan ekonomi tersebut serta jumlah penduduk yang cukup besar, maka berkembang pula aktivitas dan kegiatan masyarakat di segala bidang sehingga membutuhkan sarana penunjang yang memadai seperti peningkatan transportasi dan sektor lainnya.Saat ini kawasan pendidikan tidak lagi di tempatkan dengan semestinya, banyak dari sekolah yang ada berada di pinggir jalan raya karena sulitnya mencari area yang tepat untuk mendirikan sekolah akibat pembangunan dan pertumbuhan penduduk yang saat ini semakin pesat. Hal tersebut diperparah lagi dengan bertambahnya kepemilikan kendaraan pribadi, dan berbagai aspek permasalahan seperti manajemen lalulintas. Apalagi dilihat dari jumlah penduduk Kota Pontianak yang berjumlah 550.304 Jiwa dan luas wilayah 107, $82 \mathrm{~km}^{2}$ dan kepadatan $5.104 \mathrm{Jiwa} / \mathrm{km}^{2}$ (BPS Kota Pontianak 2010). membuat lalulintas di Kota Pontianak semakin padat sehingga berpotensi meningkatkan polusi suara yaitu kebisingan akibat transportasi.Zona Selamat Sekolah (ZoSS) adalah suatu zona untuk ruas jalan tertentu pada lingkungan sekolah dengan kecepatan yang berbasis waktu. Melalui rekayasa lalu lintas maka zona ini dilengkapi dengan fasilitas pendukung yang dapat mengatur kecepatan kendaraan. Pemilihan ZoSS sebagai lokasi penelitian bertujuan untuk meliahat pengaruh paparan kebisingan yang terjadi apakah semakin besar atau semakin kecil kebisingan setelah kendaraan melewati ZoSS.Pemetaan kebisingan adalah suatu sketsa yang menggambarkan letak ataupun posisi dari titik sampling kebisingan. Data-data tambahan berupa tingkat kebisingan di area yang diteliti. Penelitian yang akan dilakukan yaitu menganalisa tingkat kebisingan pada area zona pendidikan yang terdapat ZoSS di kota Pontianak, yaitu terbagi atas tiga lokasi penellitian yang terdapat ZoSS pada kecamatan Pontianak kota yang terdiri dari Sekolah Dasar Negrei 17 di Jalan Putri Candramidi, TK Pertiwi di Jalan KH. Ahmad Dahlan dan Sekolah Menengah Pertama Negeri 9 di Jalan Pangeran Nata Kusuma kota Pontianak.

\section{Metodologi Penelitian}

a. Lokasi Penelitian

Lokasi penelitian dilaksanakan di kawasan pendidikan yang memiliki zoss (zona selamat sekolah) kota Pontianak yaitu di Sekolah Dasar Negrei 17 di Jalan Putri Candramidi, TK Pertiwi di Jalan KH. Ahmad Dahlan dan Sekolah Menengah Pertama Negeri 9 di Jalan Pangeran Nata Kusuma kota Pontianak.

\section{b. Waktu Penelitian}

Penelitian ini dilaksanakan pada hari kerja dan waktu jam sekolah yaitu, pukul 07.00-10.00 WIB. Pemilihan waktu yang diambil mempertimbangkan jam belajar efektif pada ketiga lokasi yang akan diteliti.

$\begin{array}{ll}\text { c. } & \text { Alat yang digunakan } \\ \text { - } & \text { Sound Level Meter } \\ \text { - } & \text { Stopwatch } \\ \text { - } & \text { GPS } \\ \text { - } & \text { Counter } \\ \text { - } & \text { AplikasiSurfer } 11\end{array}$




\section{d. Pengumpulan Data}

- Observasi

Observasi merupakan tahap awal sebelum melakukan penelitian, observasi inidilakukan guna mengetahui bagaimana keadaan lokasi sebelum penelitian yang sebenarnya dengan acuan beberapa literatur dan penelitian sebelumnya yang dengan penelitian yang akan dilaksanakan. Tahap observasi dilakukan langsung ke lokasi penelitian yaitu di kawasan pendidikan kota Pontianak, untuk mendapatkan informasi dan data-data yang diperlukan dalam penelitian.

- $\quad$ Studi literatur

Studi literatur adalah mencari referensi teori yang relefan dengan kasus atau permasalahan yang ditemukan. Referensi tersebut berisikan tentang data-data untuk mendukung penelitian yang dapat bersumber dari pustaka maupun sumber lainnya

- $\quad$ Pengukuran kebisingan

Pengukuran kebisingan langsung dilokasi penelitian dengan pengukuran sederhana dengan tahapan-tahapan sesuai dengan baku mutu kebisingan yang ada.

- Perhitungan jumlah kendaraan

Penelitian dilakukan dengan mengambil data secara langsung pada pada titik sampling yang telah ditentukan sebelumnya. Perhitungan data jumlah kendaraan dilakukan dengan menggunakan counter. Jenis kendaraan akan dibedakan menjadi 2 jenis, yaitu kendaraan roda dua, kendaraan roda lebih dari dua. Dari perhitungan yang dilakukan akan didapatkan jumlah untuk masing-masing jenis kendaraan

\section{Hasil dan Pembahasan}

a. Analisis Kebisingan

- Analisis Kebisingan SDN 17 Kota Pontianak

Penelitian ini bertujuan untuk menganalisis tingkat kebisingan pada kawasan SDN 17 Kota Pontianak. Penelitian dilakukan pada 9 titik dengan waktu pengukuran 10 menit pada setiap titik dengan jumlah data sebanyak 120 data. Berikut adalah data nilai rata-rata kebisingan pada SDN 17 kota Pontianak dapat dilihat pada tabel 1.

Tabel 1 Nilai Rata-rataKebisingan SDN 17 Kota Pontianak

\begin{tabular}{|c|c|}
\hline \multirow{3}{*}{ Titik } & Nilai kebisingan (Db) \\
\cline { 2 - 2 } & Waktu Pengukuran \\
\cline { 2 - 2 } & 07.00 - 10.00 WIB \\
\cline { 2 - 2 } & Rata - rata \\
\hline 1 & 71.7 \\
\hline 2 & 70.4 \\
\hline 3 & 71.0 \\
\hline 4 & 68.9 \\
\hline 5 & 66.5 \\
\hline 6 & 72.5 \\
\hline 7 & 66.9 \\
\hline 8 & 68.3 \\
\hline 9 & 72.8 \\
\hline
\end{tabular}

Berdasarkan Tabel 1 diatas dapat dilihat bahwa tingkat kebisingan kebisingan di SDN 17 Kota Pontianak telah melebihi ambang batasMenteri Negara Lingkungan Hidup Nomor KEP.48/MENLH/11/1996, yaitu sebesar $55 \mathrm{~dB}$. Tingkat kebisingan tertinggi berada pada titik pengukuran ke 9 dengan nilai sebesar $72,8 \mathrm{~dB}$ sedangkan tingkat kebisingan terendah di SDN 17 kota Pontianak terdapat pada titik pengukuran ke 5 dengan nilai sebesar $66,5 \mathrm{~dB}$ pada rentang waktu pengukuran yang sama. 
- $\quad$ Analisis Kebisingan TK Pertiwi Kota Pontianak

Penelitian ini bertujuan untuk menganalisis tingkat kebisingan pada kawasan TK Pertiwi Kota Pontianak. Penelitian dilakukan pada 9 titik dengan waktu pengukuran 10 menit pada setiap titik dengan jumlah data sebanyak 120 data. Berikut adalah data nilai rata-rata kebisingan pada TK Pertiwi kota Pontianak dapat dilihat pada tabel 2.

Tabel 2. Nilai Rata-rata Kebisingan TK Pertiwi Kota Pontianak

\begin{tabular}{|c|c|}
\hline \multirow{3}{*}{ Titik } & Nilai kebisingan (Db) \\
\cline { 2 - 2 } & Waktu Pengukuran \\
\cline { 2 - 2 } & 07.00 - 10.00 WIB \\
\cline { 2 - 2 } & Rata - rata \\
\hline 1 & 58.2 \\
\hline 2 & 67.2 \\
\hline 3 & 63.2 \\
\hline 4 & 62.5 \\
\hline 5 & 60.0 \\
\hline 6 & 65.1 \\
\hline 7 & 61.2 \\
\hline 8 & 55.6 \\
\hline 9 & 68.7 \\
\hline
\end{tabular}

Berdasarkan Tabel 2 diatas dapat dilihat bahwa tingkat kebisingan kebisingan di SDN TK Pertiwi Kota Pontianak telah melebihi ambang batas Menteri Negara Lingkungan Hidup Nomor KEP.48/MENLH/11/1996, yaitu sebesar $55 \mathrm{~dB}$. Tingkat kebisingan tertinggi berada pada titik pengukuran ke 9 dengan nilai sebesar $68,7 \mathrm{~dB}$ sedangkan tingkat kebisingan terendah di TK Pertiwi kota Pontianak terdapat pada titik pengukuran ke 8 dengan nilai sebesar $56,5 \mathrm{~dB}$ pada rentang waktu pengukuran yang sama.

\section{- $\quad$ Analisis Kebisingan SMPN 9 Kota Pontianak}

Penelitian ini bertujuan untuk menganalisis tingkat kebisingan pada kawasan SMPM 9 Kota Pontianak. Penelitian dilakukan pada 9 titik dengan waktu pengukuran 10 menit pada setiap titik dengan jumlah data sebanyak 120 data. Berikut adalah data nilai rata-rata kebisingan pada SMPN 9 kota Pontianak dapat dilihat pada tabel 3.

\begin{tabular}{|c|c|}
\hline \multirow{3}{*}{ Titik } & Nilai kebisingan (Db) \\
\cline { 2 - 2 } & Waktu Pengukuran \\
\cline { 2 - 2 } & 07.00 - 10.00 WIB \\
\cline { 2 - 2 } & Rata - rata \\
\hline 1 & 68.5 \\
\hline 2 & 70.2 \\
\hline 3 & 70.7 \\
\hline 4 & 56.7 \\
\hline 5 & 57.5 \\
\hline 6 & 60.8 \\
\hline 7 & 52.3 \\
\hline 8 & 58.1 \\
\hline 9 & 61.8 \\
\hline
\end{tabular}

Berdasarkan Tabel 3 diatas dapat dilihat bahwa tingkat kebisingan kebisingan di SMPN 9 Kota Pontianak telah melebihi ambang batas Menteri Negara Lingkungan Hidup Nomor KEP.48/MENLH/11/1996, yaitu sebesar $55 \mathrm{~dB}$. Tingkat kebisingan tertinggi berada pada titik 
pengukuran ke 3 dengan nilai sebesar 70,7 dB sedangkan tingkat kebisingan terendah di SMPN 9kota Pontianak terdapat pada titik pengukuran ke 7 dengan nilai sebesar 53,3 dB pada rentang waktu pengukuran yang sama.

\section{b. Pemetaan Kebisingan}

\section{- Pemetaan Kebisingan SDN 17 Kota Pontianak}

Pemetaan tingkat kebisingan dilakukan dengan menentukan titik survei pada aplikasi Google Earth. Koordinat titik survei dan nilai kebisingan yang diperoleh dibuatkan kontur untuk mengetahui sebaran tingkat kebisingan di kawasan SDN 17 kota Pontianak. Peta kontur tingkat kebisingan di kawasan SDN 17 kota Pontianak dapat dilihat pada gambar 1. dan peta sebaran tingkat kebisingan di dapat dilihat pada gambar 2 .

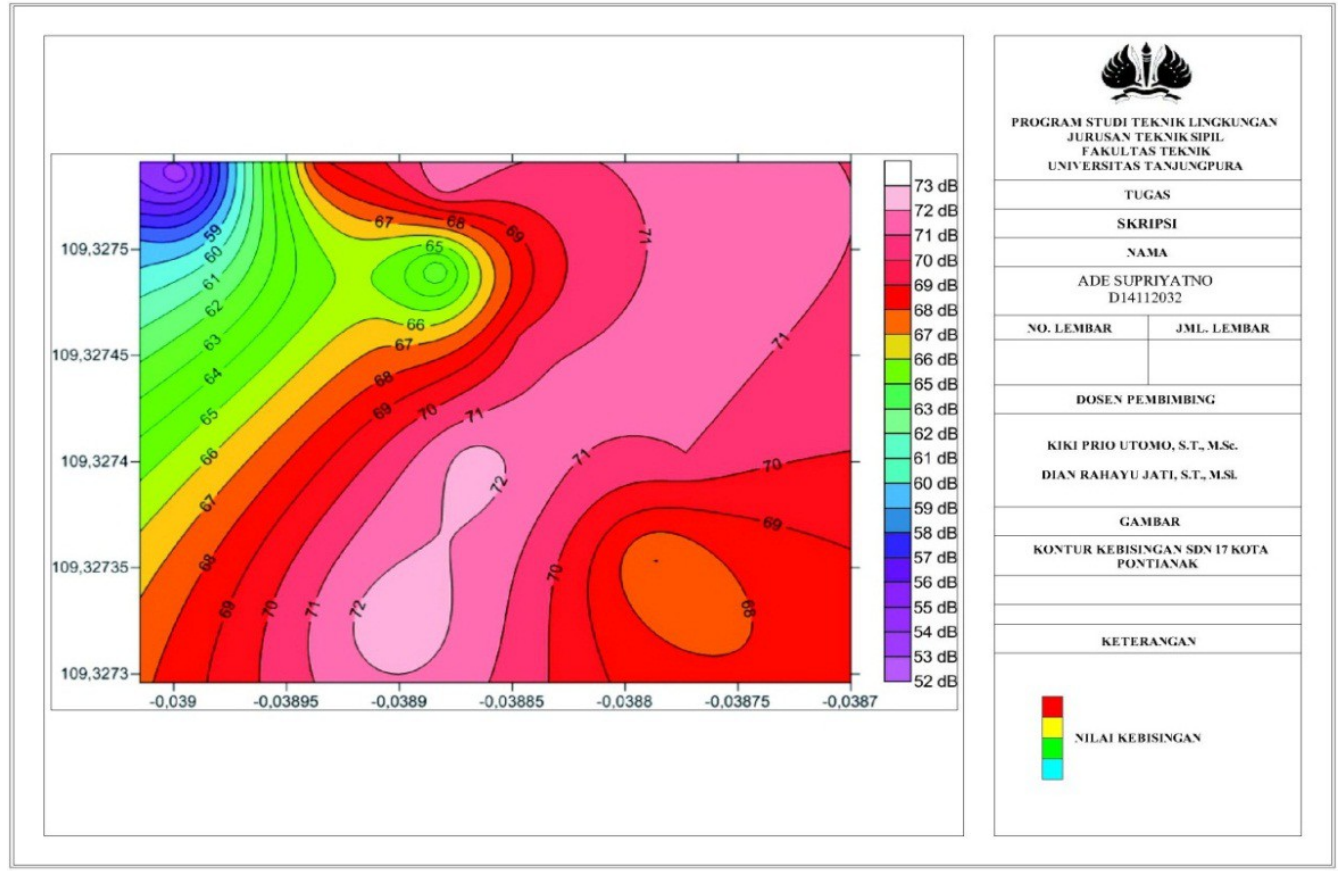

Gambar1.PetabKontur Rata - Rata Kebisingan di SDN 17 Kota Pontianak

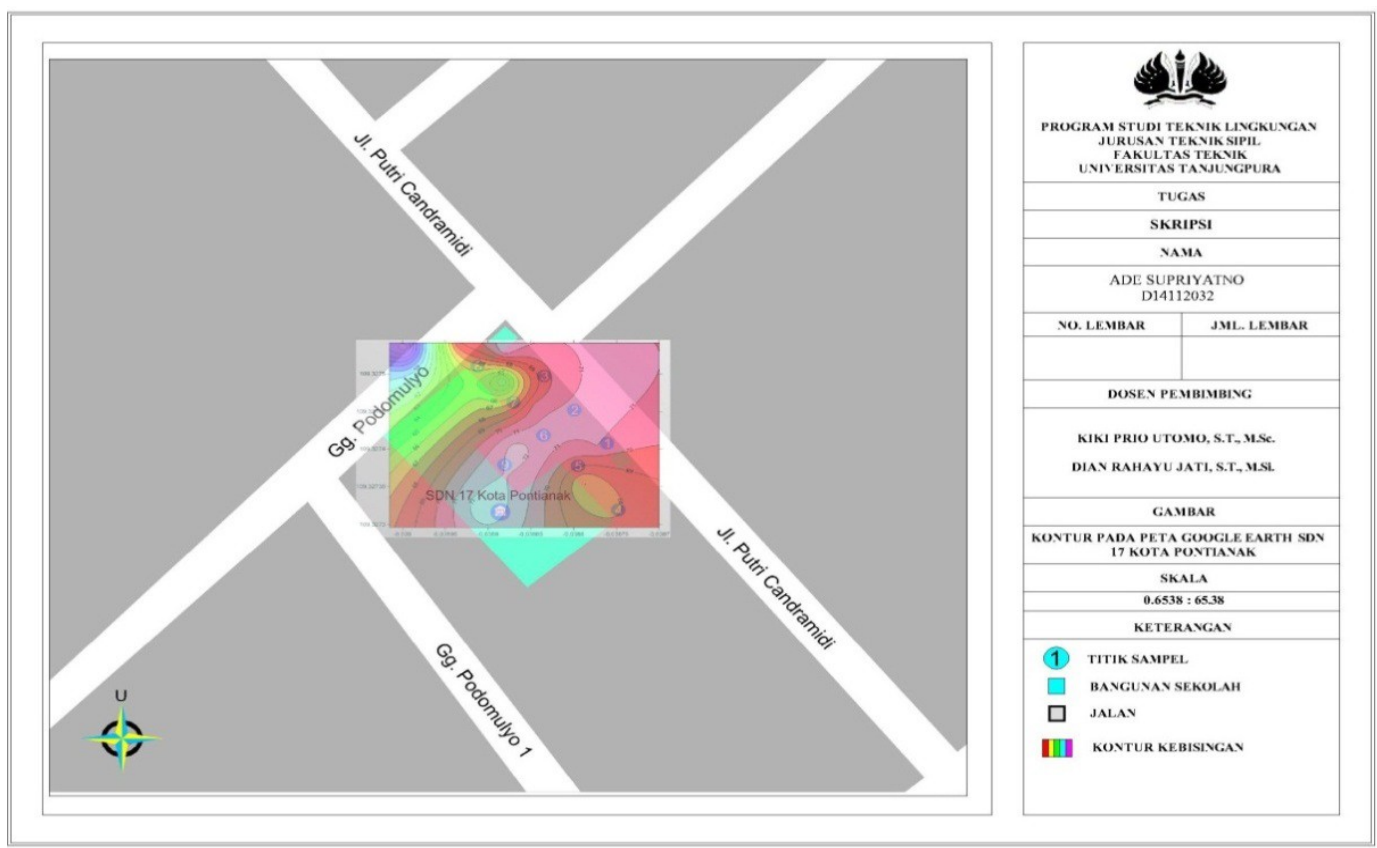

Gambar2.Kontur Pada Peta Google Earth di SDN 17 Kota Pontianak 
Berdasarkan gambar di atas, tingkat kebisingan di atas $70 \mathrm{~dB}$ yang ditandai dengan warna merah terdapat pada titik $1,2,3,6$, dan 9. Titik-titik tersebut memiliki tingkat kebisingan yang tinggi karena untuk titik 1, 2, dan 3 berada di pinggir jalan, dan titik 6 dan 9 berwarna merah karena berada di area lapangan sekolah dan merupakan tempat terbuka karena tidak adanya penghalang pada bagian tepi jalan yaitu sejajar dengan titik 2. Penyebab lain karena tingkat kebisingan pada titik tersebut diukur pada saat ada aktivitas di lapangan yaitu para siswa sedang ada jam pelajaran olahraga banyak siswa yang berkeliaran sekitaran bagian bangunan sekolah. Kebisingan dengan tingkat kebisingan antara $60-70 \mathrm{~dB}$ ditandai dengan warna biru, hijau, kuning dan merah terdapat pada titik 4, 5, 7, dan 8. Seperti dilihat pada gambar di atas, titik yang berwarna orange berada di diparkiran guru yaitu titik 4 . Tingkat kebisingan di area tempat parkir ini lebih rendah di bandingkan dengan yang di lapangan. Hal itu terjadi karena adanya pohon dan berada pada bagian tepi pagar sekolah. Untuk titik 5,7, dan 8 Kebisingannya di bawah $70 \mathrm{~dB}$ ditandai dengan warna ungu yang terdapat Seperti dilihat pada gambar di atas, untuk 5 berada di depan kantor guru, dimana di bagian depan terdapat pos satpam sedangkan untuk titik 7 dan 8 berada di dekat kantin, sehingga suara bising dari arah jalan cukup teredam karna adanya bangunan tersebut dan juga beberapa pohon sebagai penghalang.

\section{- Pemetaan Kebisingan TK Pertiwi Kota Pontianak}

Pemetaan tingkat kebisingan dilakukan dengan menentukan titik survei pada aplikasi Google Earth. Koordinat titik survei dan nilai kebisingan yang diperoleh dibuatkan kontur untuk mengetahui sebaran tingkat kebisingan di kawasan TK Pertiwi kota Pontianak. Peta kontur tingkat kebisingan di kawasan TK Pertiwi kota Pontianak dapat dilihat pada gambar 3. dan peta sebaran tingkat kebisingan di dapat dilihat pada gambar 3.

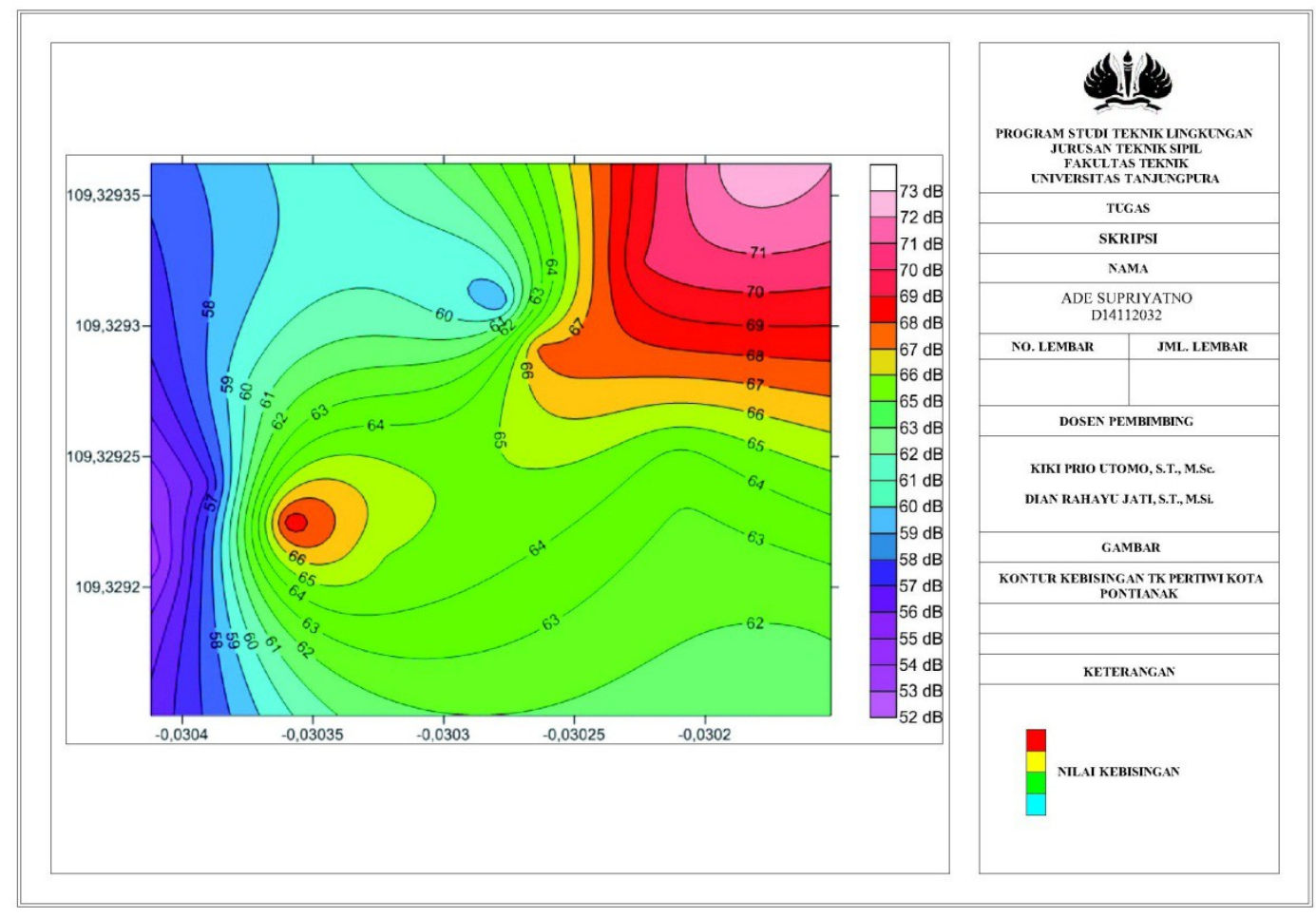

Gambar 3.Peta Kontur Rata-Rata Kebisingan di TK Pertiwi Kota Pontianak 


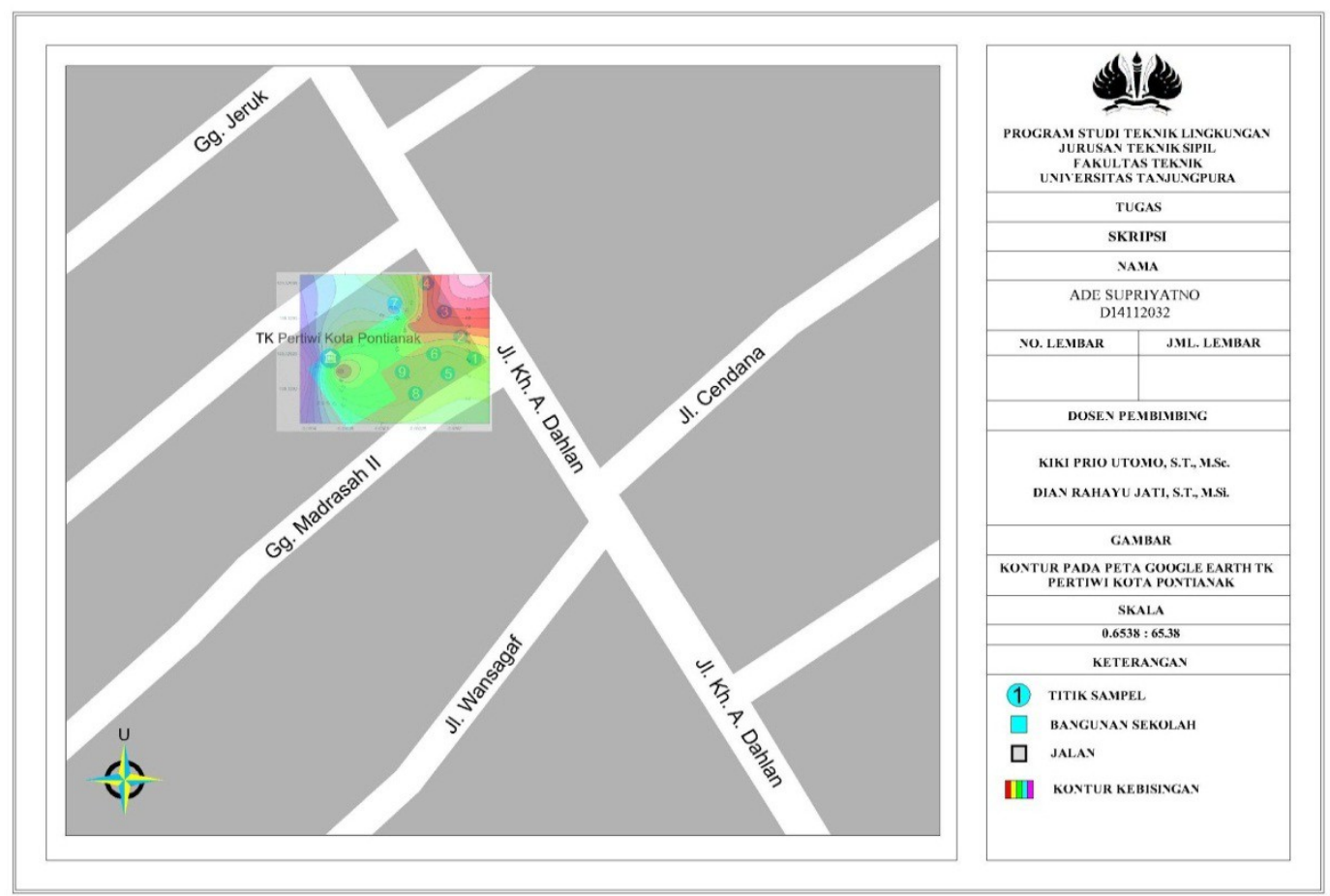

Gambar 4. Kontur Pada Peta Google Earth TK Pertiwi Kota Pontianak

Berdasarkan gambar di atas, tingkat kebisingan di atas $60 \mathrm{~dB}$ yang ditandai dengan warna biru, hijau, kuning, merah, dan putih terdapat pada titik 2, 3, 4, 5, 6, 7, dan 9. Titik-titik tersebut memiliki tingkat kebisingan yang tinggi karena untuk titik 2,3 , dan 4 berada di pinggir jalan dan di tandai dengan kontur berwarna merah, dan titik 6 dan 9 juga berwarna merah karena berada di area lapangan sekolah dan merupakan tempat terbuka karena tidak adanya penghalang pada bagian tepi jalan yaitu sejajar dengan titik 2. Penyeabab lain karena tingkat kebisingan pada titik tersebut diukur pada saat ada aktivitas di dalam area yaitu para siswa sedang ada aktivitas belajar. Untuk titik 7 berwarna biru berada di area parkiran dekat ruang kelas, hal tersebut di karenakan ada sumber aktivitas di dalam kelas. Kebisingan dengan tingkat kebisingan antara 55-60 dB ditandai dengan warna ungu, biru, terdapat pada titik 1,5 , dan 8 . Seperti dilihat pada gambar di atas, titik-titik yang berwarna ungu berada sejajar dengan pagar yang cukup tinggi sehingga suara bising dari arah jalan A.Yani sebagian terpantulkan kembali kearah yang sebaliknya dan teredam sehingga suara bising dari transportasi kendaraan sedikit terhalang pagar pembatas.

\section{- PemetaanKebisingan SMPN 9 Kota Pontianak}

Pemetaan tingkat kebisingan dilakukan dengan menentukan titik survei pada aplikasi Google Earth. Koordinat titik survei dan nilai kebisingan yang diperoleh dibuatkan kontur untuk mengetahui sebaran tingkat kebisingan di kawasan SMPN 9 kota Pontianak. Peta kontur tingkat kebisingan di kawasan SMPN 9 kota Pontianak dapat dilihat pada gambar 5. dan peta sebaran tingkat kebisingan di dapat dilihat pada gambar 6 . 


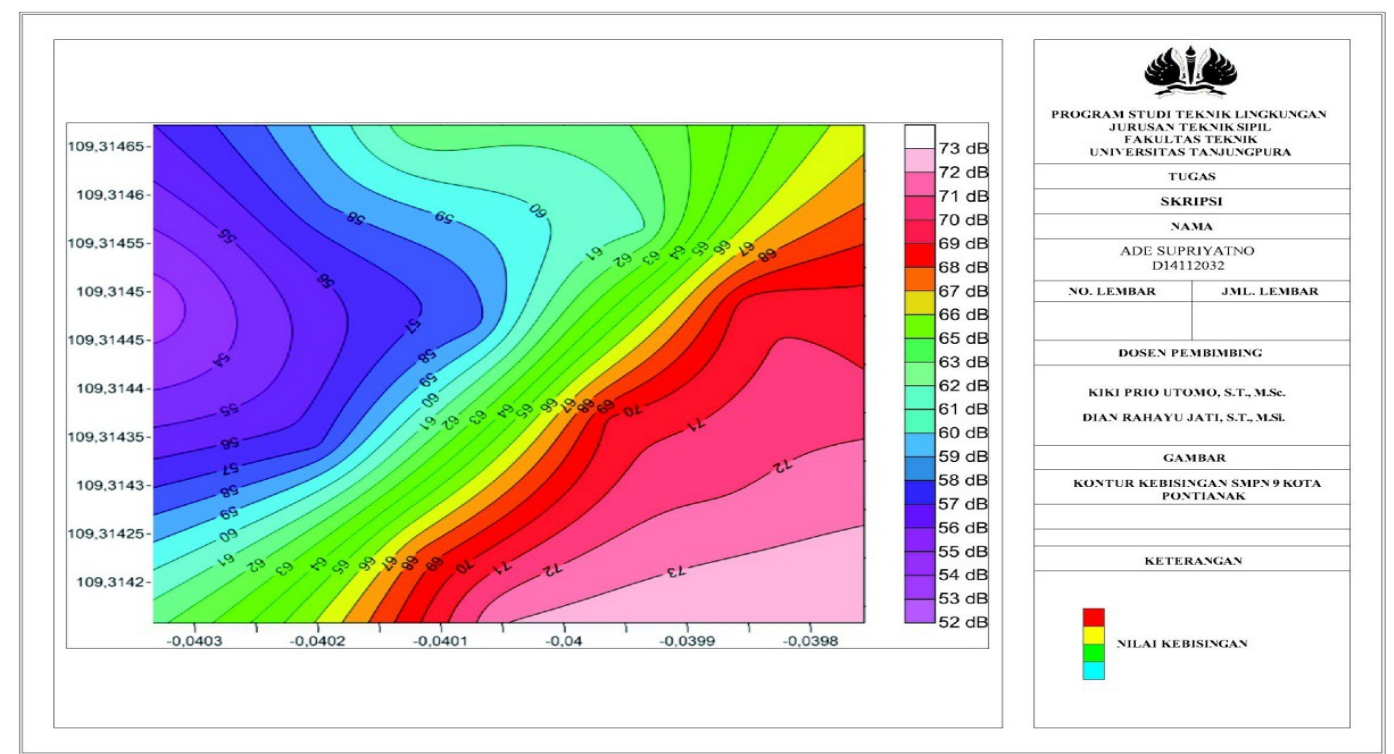

Gambar 5. Peta Kontur Rata-Rata Kebisingan di SMPN 9 Kota Pontianak

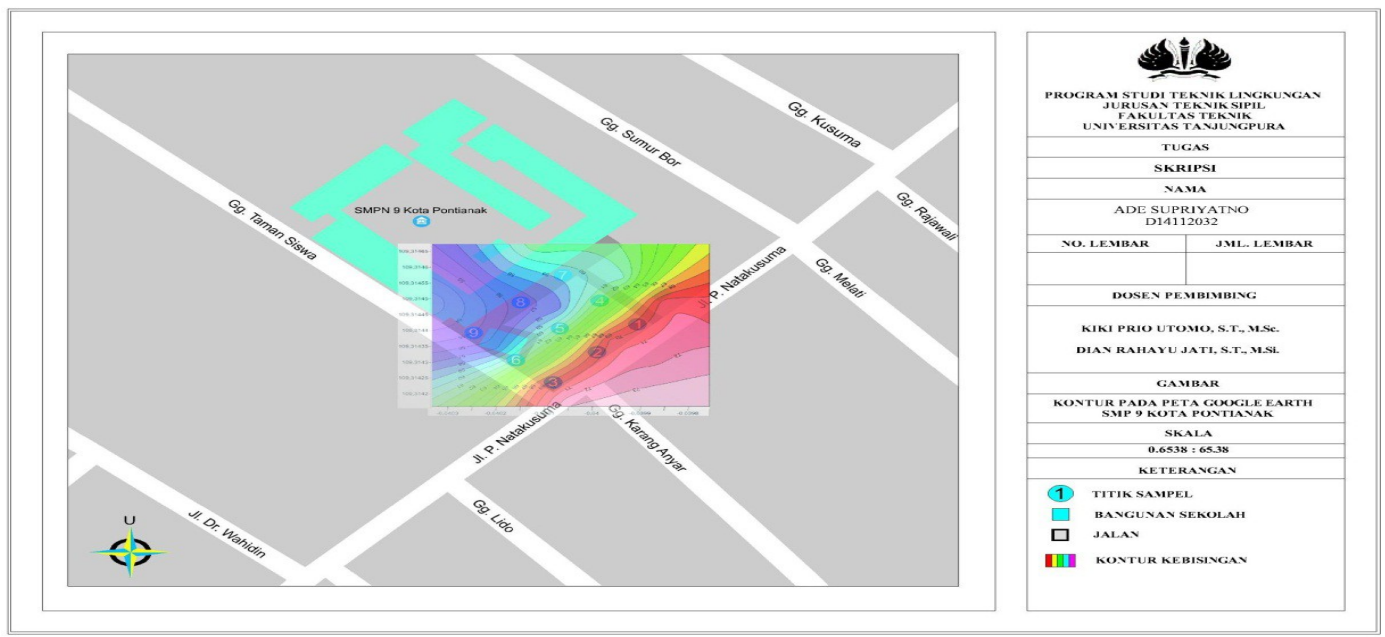

Gambar 6.Kontur Pada Peta Google Earth SMPN 9 Kota Pontianak

Berdasarkan gambar di atas, tingkat kebisingan mendekati $70 \mathrm{~dB}$ yang ditandai dengan warna hijau, kuning, merah, dan putih terdapat pada titik 1,2, dan 3. Titik-titik tersebut memiliki tingkat kebisingan yang tinggi karena untuk titik 1, 2, dan 3 berwarna merah karena berada di pinggir jalan Pangeran Natakusuma, sehingga kebisingan pada titik tersebut menjadi tinggi. Kebisingan dengan tingkat kebisingan antara $55-62 \mathrm{~dB}$ ditandai dengan warna ungu, biru, terdapat pada titik 4, 5, 6, 8, dan 9. Untuk titik pengukuran 4, 5, dan 6 berada di tengah halaman depan sekolah. Pada titik ke 7 nilai kebisingan yang terukur di bawah $55 \mathrm{~dB}$ yaitu baku mutu kebisingan, hal ini dikarenakan jarak yang cukup jauh dari jalan, juga pada beberapa bagian terdapat pohon, sehingga suara bising dari arah jalan bisa sedikit berkurang. Untuk titik 8 dan 9 berada pada samping kelas dan memiliki jarak yang terjauh dari jalan raya, namun pada titik 9 nilainya lebih tinggi di bandingkan titik 4, 5, dan 6 hal ini dikarenakan pada saat pengukuran terdapat aktivitas dari arah kelas sehingga nilai kebisingan nya sedikit lebih tinggi. Pada titik 7 memiliki nilai kebisingan 52,3 dB, nilai ini merupakan yang terendah dari semua titik dan artinya masih masuk dalam standar baku mutu.

\section{c. Upaya Mengatasi Kebisingan}

- Penanganankebisinganpadajalur perambatan suara umumnya dilakukan dengan pemasangan peredam bising (BPB). PB dapat berupa penghalang alami (natural barrier) dan penghalang buatan (artificial barrier). BPB umumnya memiliki karakteristik secara teknis dapat menurunkan tingkat kebisingan antara $10 \mathrm{~s} . \mathrm{d} 15 \mathrm{~dB}$, mampu mencapai pengurangan tingkat 
kebisingan sebesar $5 \mathrm{~dB}$ apabila cukup tinggi untuk memotong jalur perambatan gelombang suara dari sumber ke penerima serta setiap penambahan $1 \mathrm{~m}$ ketinggian diatas jalur perambatan gelombang dapat menurunkan tingkat kebisingan sebesar $1,5 \mathrm{~dB}$ dengan penurunan maksimum secara teoritis sebesar 20 dB (Departemen Pekerjaan Umum, 2005).

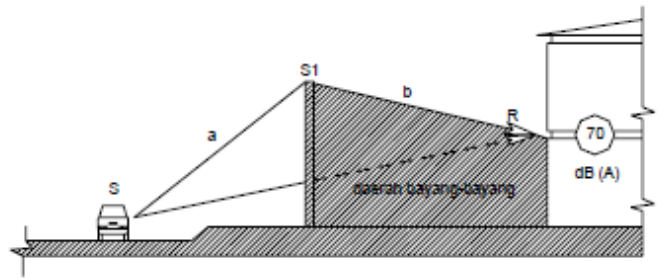

Gambar 7 Kondisi Dengan Bangunan Peredam Bising

- Tanaman yang digunakan untuk penghalang kebisingan harus memiliki kerimbunan dakerapatan daun yang cukup dan merata mulai dari permukaan tanah hingga ketinggian yang diharapkan. Untuk itu, perlu diatur suatu kombinasi antara tanaman penutup tanah, perdu, dan pohon atau kombinasi dengan bahan lainnya sehingga efek penghalang menjadi optimum. Tanaman-tanaman yang dapat digunakan salah satunya adalah tanaman Seba (Heliconia Sp) dapat mereduksi kebisingan sebesar 3,4 dB.

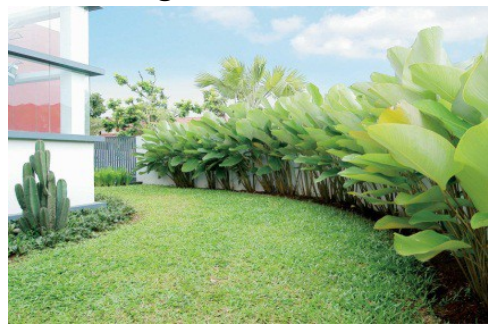

Gambar 8 Seba (Heliconia Sp)

- Kebijakan tentang transportasi pada uu nomor 14 tahun 1992 tentang lalu lintas dan angkutan jalan pada pasal 50 ,Untuk mencegah pencemaran udara dan kebisingan suara kendaraan bermotor yang dapat mengganggu kelestarian lingkungan hidup, setiap kendaraan bermotor wajib memenuhi persyaratan ambang batas emisi gas buang dan tingkat kebisingan. Setiap pemilik, pengusaha angkutan umum dan/atau pengemudi kendaraan bermotor, wajib mencegah terjadinya pencemaran udara dan kebisingan sebagaimana dimaksud dalam ayat (1), yang diakibatkan oleh pengoperasian kendaraannya. Secara konvensional, perencanaan transportasi perkotaan (urban tranpostation planning) dilaksanakan dalam empat tahap (for stage planning), yaitu, bangkitan perjalanan (trip generation), distribusi perjalanan (trip distribution), pemilahan moda (modal split), pelimpahan rute (trip assgnment). Salah satu yang bisa menjadi alternatif kebijakan yaitu modal split yaitu pergantian moda perjalanan orang dan barang yang dipindahkan ke arah yang lebih berkelanjutan seperti berjalan kaki, bersepeda, angkutan umum.

\section{Kesimpulan}

1. Tingkat kebisingan di SDN 17 ,TK Pertiwi dan SMPN 9 kota Pontianak telah melebihi ambang batas kebisingan untuk sekolah dalam Keputusan Menteri Negara Lingkungan Hidup Nomor KEP.48/MENLH/11/1996 yaitu sebesar 55 dBA. Tingkat kebisingan tertinggi di SDN 17 kota Pontianak yaitu sebesar $72,8 \mathrm{~dB}$.

2. Pemetaan kebisingan pada kawasan pendidikan kota Pontianak pada masing-masing daerah telah melebihi ambang batas baku mutu kebisngan. Berdasarkan gambar kontur pada pemetaan kebisingan warna kontur terdiri atas 7 warna yaitu warna ungu, biru, hijau, kuning, merah, orange, dan putih. Penggolongan warna tersebut didasarkan atas nilai tingkat kebisingan. warna ungu untuk tingkat kebisingan paling rendah dengan intensitas 52-57 dB, warna biru untuk tingkat kebisingan dengan intensitas kebisingan 58-61 dB, warna hijau untuk 
tingkat kebisingan dengan intensitas 62-67 dB, warna kuning untuk tingkat kebisingan dengan intensitas $68 \mathrm{~dB}$, warna merah untuk tingkat kebisingan dengan intensitas 69-73 dB, dan warna putih untuk tingkat kebisingan lebih dari $73 \mathrm{~dB}$.

3. Upaya untuk meminimalisir kebisingan dari aktivitas transportasi di Pontianak yaitu membuat BPB dapat berupa penghalang alami (natural barrier) dan penghalang buatan (artificial barrier), Menambahkan tanaman yang dapat meredam bising. Serta untuk pemerintah kota bisa membuat kebijakan mengenai pemakaian moda transportasi umum.

\section{Ucapan Terimakasih}

Dengan selesainya penelitian ini saya mengucapkan terima kasih yang sebesar-besarnya kepada Allah SWT, kedua orang tua, kedua dosen pembimbing yaitu bapak kiki prio utomo, S.T., M.Sc dan Ibu Dian Rahayu Jati, S.T., M.si, kedua dosen penguji yaitu Ibu Yulisa Fitrianingsih, S.T., M.T dan Ibu Laili Fitria, S.T., M.T serta teman-teman Teknik Lingkungan 2012 dan semua orang yang telah berperan dalam membantu penelitian yang tidak dapat diucapkan satu persatu. Harapan saya penelitian ini dapat bermanfaat bagi semua dan dapat dipergunakan sebagaimana mestinya.

\section{Daftar Pustaka}

Buchari. 2007. Kebisingan Industri dan Hearing Conservation Program. USU Repository: Universitas Sumatera Utara.

Djalante, S. 2010. Analisis Tingkat Kebisingan Di Jalan Raya Yang Menggunakan Alat Pemberi Isyarat Lalu Lintas (APIL) (Studi Kasus: Simpang

Departemen Kesehatan RI, Pelunjuk Pelaksanaan Pengawasan Keb isingan.Jakarta: Departemen Kesehatan RI, 1995.

Harrington, \& Gill, 2005. Buku Saku Kesehatan Kerja . Jakarta : EGC

Hidayati, N. 2007. Pengaruh Arus Lalu Lintas Terhadap Kebisingan (Studi Kasus Beberapa Zona Pendidikan Di Surakarta). Dinamika TEKNIK SIPIL. Volume 7, No. 1, Januari 2007: 45-54.

Ikron, Djaja, I. M., dan Wulandari, R. A. 2005. Pengaruh Kebisingan Lalu Lintas Jalan Terhadap Gangguan Kesehatan Psikologi Anak SDN Cipinang Muara Kecamatan Jatinegara Kota Jakarta Timur Propinsi DKI Jakarta. Makara, Kesehatan. VOL. 11, NO. 1, Juni 2007: 32-37.

Leksono, R.A.2009. Gambaran Kebisingan diArea Kerja Shop C-D Unit Usaha Jembatan : Universitas Indonesia

Menteri Lingkungan Hidup. 1996. Tentang: Baku Kebisingan. Surat Keputusan Menteri Lingkungan Hidup Nomor: Kep-48/MENLH/1996/25 November 1996. Jakarta.

Peraturan Daerah Kota Pontianak Nomor 2 Tahun 2013 Tentang Rencana Tata Ruang Wilayah Kota Pontianak Tahun 2013-2033. Pontianak

Purwadi, J. 2006. Analisis Tingkat Kebisingan Dan Emisi Gas Buang Di Jalan Slamet Riyadi Dan Alternatif Solusinya (Kajian Empirikal dan Non Empirikal). Progam Magister Teknik Sipil Universitas Muhammadiyah Surakarta.

Satwiko, P. 2004. Fisika Bangunan 2 (edisi 1). Yogyakarta: Penerbit ANDI.

Satwiko, P. 2005. Fisika Bangunan 1 (edisi 2). Yogyakarta: Penerbit ANDI.

Setiawan, F. N. 2010. Tingkat Kebisingan Pada Perumahan Di Perkotaan. JurnalTeknik Sipil dan Perencanaan, No.2, Volume 12 - Juli 2010: 191-200.

Soedojo, P. 2004. Fisika Dasar. Yogyakarta: Penerbit ANDI.

Suroto, W. 2010. Dampak Kebisingan Lalu Lintas Terhadap Pemukiman Kota (Kasus Kota Surakarta). Jurnal of Rulan and Development. Volume 1, No. 1 Februari 2010.

Undang-undang Nomor 14, Tahun 1992 Tentang Lalu Lintas Dan Angkutan Jalan, Indonesia 